\title{
Editorial
}

Folia Phoniatrica et Logopaedica
Folia Phoniatr Logop 2007;59:53-54

DOI: $\underline{10.1159 / 000098337}$

\section{April 16th: The World Voice Day}

\author{
Jan G. Švec ${ }^{a, b}$ Mara Behlau ${ }^{c}$ \\ ${ }^{a}$ Groningen Voice Research Lab, University of Groningen, Groningen, The Netherlands; \\ ${ }^{b}$ Centre for Communication Disorders, Medical Healthcom, Ltd., Prague, Czech Republic; \\ ${ }^{c}$ Centro de Estudos da Voz (CEV), São Paulo, Brazil
}

\section{Key Words}

Interdisciplinarity $\cdot$ Science and arts • Voice disorders •

World Voice Day

\begin{abstract}
Although the voice is used as an everyday basis of speech, most people realize its importance only when a voice problem arises. Increasing public awareness of the importance of the voice and alertness to voice problems are the main goals of the World Voice Day, which is celebrated yearly on April 16th. The event started as a national initiative in Brazil in 1999 and quickly spread internationally. The article provides a brief history of the World Voice Day, together with basic background information. Copyright $\odot 2007$ S. Karger AG, Basel
\end{abstract}

Metaphorically, the voice is a window to the soul. The voice can reveal moods, age or illness. We can be charmed by someone's voice; the voice can be used to calm, but also to provoke or scare. The ability of the voice to communicate emotions and to influence others in a positive or negative way is an important factor in today's society, which relies on the voice as a working tool. Professional singers and teachers are prominent examples of people who owe their living to the voice, and so do also many

\section{KARGER}

Fax +4161306 1234

E-Mail karger@karger.ch

www.karger.com
(C) 2007 S. Karger AG, Basel

1021-7762/07/0592-0053\$23.50/0

Accessible online at: www.karger.com/fpl other professions, such as actors, reporters, lawyers, auctioneers, phone assistants, etc. $[1,2]$. The number of workers relying on human communication is increasing while the number of manual workers is decreasing [3]. In such a society, voice problems have an impact on people's professional carriers and their quality of life [4-9].

The World Voice Day was established on April 16th with the main goals of increasing public awareness of the importance of the voice and alertness to voice problems. The event started in Brazil in 1999 as the Brazilian National Voice Day. It was the result of a mixed initiative of physicians, speech-language pathologists and singing teachers that belonged to the former association 'Sociedade Brasileira de Laringologia e Voz - SBLV' (Brazilian Society of Laryngology and Voice). This initiative was followed by other countries, such as Argentina and Portugal, and the Brazilian National Voice Day became the International Voice Day. In the United States, the American Academy of Otolaryngology - Head and Neck Surgery officially recognized this celebration in 2002 and in that year the event obtained the name 'World Voice Day' [10].

Written by the authors on behalf of the Voice Committee of the International Association of Logopedics and Phoniatrics. 
Although the voice is used as an everyday basis of speech, most people realize its importance only when a voice problem arises. Often, these problems are only temporary, such as in case of hoarseness due to common cold, or due to vocal fatigue after an extensive period of talking. However, the problems may become chronic if the voice is abused or overused when vulnerable. The risk of voice damage is increased especially during upper respiratory infections [11]. It is important to prevent abusive vocal behavior that can lead to permanent voice damage. The voice results from vibration of the vocal folds, the structure of which is highly delicate and can be damaged $[12,13]$. Blood vessels on the vocal folds may rupture during crying or during exceedingly loud vocalizations [11]. Normally, the wound is expected to heal spontaneously, but when the voice is being constantly used and the tissue of the vocal folds keeps being irritated, the healing processes are disturbed, leading to a development of pathology causing permanent voice change. If voice problems last more than three weeks, they may indicate developing laryngeal pathology and therefore should be examined by a specialist physician.

Besides voice awareness, the World Voice Day can be taken as a celebration of interdisciplinarity and interaction between arts and science. Vocal artists depend on their voice, and dealing with their voice problems requires excellent knowledge of the vocal apparatus and its functioning. Detailed understanding of the production and perception of the human voice benefits from an interdisciplinary approach. The voice is a topic of interest to otolaryngologists/phoniatricians, logopedists/speech pathologists, singing teachers, vocologists, acousticians, biomechanical engineers and many other specialists. Collaboration among specialists with a different background is of crucial importance for improving knowledge of the human voice and should be encouraged. An important role is played here by interdisciplinary societies such as the Voice Foundation or the International Association of Logopedics and Phoniatrics (IALP). There has been a considerable development towards interdisciplinarity over the last decades, which is reflected in several regularly organized interdisciplinary meetings on the subject of voice production, such as the Voice Foundation's annual symposium 'Care of the Professional Voice' in Philadelphia, USA, the biennial Pan-European Voice Conference (PEVOC) or the biennial International Conference on Voice Physiology and Biomechanics (ICVPB). At these meetings, professionals with different backgrounds meet and discuss problems related to voice production. Growing numbers of participants at these conferences promise that interdisciplinary collaboration will contribute to a better understanding of voice production, as well as better treatment, management and care of voice.

Overall, the World Voice Day offers an opportunity to spread knowledge and increase public awareness of the human voice. Societies and institutes are encouraged to organize various types of related events, similar to those occurring in Brazil, such as media interviews, talk shows, public presentations, vocal counseling, voice screenings, laryngeal examinations, voice performances, etc. It is our hope that the World Voice Day will grow further and reflect the increasing importance of the human voice in today's society and people's quality of life.

\section{References}

$>1$ Titze IR, Lemke J, Montequin D: Population in the U.S. workforce who rely on voice as a primary tool of trade: a preliminary report. J Voice 1997;11:254-259.

$>2$ Fritzell B: Voice disorders and occupations. Logoped Phoniatr Vocol 1996;21:7-12.

$>3$ Ruben RJ: Redefining the survival of the fittest: communication disorders in the 21 st century. Laryngoscope 2000;110:241-245.

$\checkmark 4$ Cohen SM, Garrett CG, Dupont WD, Ossoff $\mathrm{RH}$, Courey MS: Voice-related quality of life in T1 glottic cancer: irradiation versus endoscopic excision. Ann Otol Rhinol Laryngol 2006;115:581-586.
5 Krischke S, Weigelt S, Hoppe U, Köllner V, Klotz M, Eysholdt U, Rosanowski F: Quality of life in dysphonic patients. J Voice 2005;19: 132-137.

6 Rasch T, Gunther S, Hoppe U, Eysholdt U, Rosanowski F: Voice-related quality of life in organic and functional voice disorders. Logoped Phoniatr Vocol 2005;30:9-13.

7 Vilkman E: Occupational safety and health aspects of voice and speech professions. Folia Phoniatr Logop 2004;56:220-253.

$\checkmark 8$ Wilson JA, Deary IJ, Millar A, MacKenzie K: The quality of life impact of dysphonia. Clin Otolaryngol 2002;27:179-182.

$>9$ Verdolini K, Ramig LO: Review: occupational risks for voice problems. Logoped Phoniatr Vocol 2001;26:37-46.
10 Anonymous: World Voice Day: American Academy of Otolaryngology - Head and Neck Surgery (http://www.entnet.org/ VoiceDay), 2002.

11 Murry T, Rosen CA: Phonotrauma associated with crying. J Voice 2000;14:575-580.

12 Gray SD, Titze IR, Lusk RP: Electron microscopy of hyperphonated canine vocal cords. J Voice 1987;1:109-115.

13 Gray SD, Pignatari SS, Harding P: Morphologic ultrastructure of anchoring fibers in normal vocal fold basement membrane zone. J Voice 1994;8:48-52. 